Contrib. Mineral. Petrol. 48, 153-169 (1974)

(C) by Springer-Verlag 1974

\title{
Strontium Isotope Composition and Petrogenesis of the Kirkpatrick Basalt, Queen Alexandra Range, Antarctica*
}

\author{
G. Faure, J. R. Bowman**, D. H. Elliot, and L. M. Jones***
}

Department of Geology and Mineralogy and Institute of Polar Studies, The Ohio State University, Columbus, Ohio 43210

Received May 3, 1974; Revised October 16, 1974

Abstract. The initial ${ }^{87} \mathrm{Sr} /{ }^{86} \mathrm{Sr}$ ratios of twelve basalt flows of Jurassic age on Storm Peak in the Queen Alexandra Range are anomalously high and range from $0.7094-0.7133$. The average value is $0.7112 \pm 0.0013(1 \sigma)$. The concentrations of rubidium and strontium have arithmetic means of $60.6 \pm 19.4 \mathrm{ppm}$ and $128.8 \pm 11.9 \mathrm{ppm}$, respectively. The corresponding average $\mathrm{Rb} / \mathrm{Sr}$ ratio is 0.47 which is also anomalously high for rocks of basaltic composition. In addition, these rocks have high concentrations of $\mathrm{SiO}_{2}(56.50 \%)$ and $\mathrm{K}_{2} \mathrm{O}(1.29 \%)$ and are depleted in $\mathrm{Al}_{2} \mathrm{O}_{3}(12.92 \%), \mathrm{MgO}(3.44 \%)$ and $\mathrm{CaO}(7.91 \%)$ compared to average continental tholeiites. They are nevertheless classified as basalts on the basis of the composition of microphenocrysts.

The initial ${ }^{87} \mathrm{Sr} /{ }^{86} \mathrm{Sr}$ ratios and all of the chemical parameters of the flows exhibit systematic stratigraphic variations. These are interpreted as indicating the occurrence of four eruptive cycles. In a typical cycle the initial ${ }^{87} \mathrm{Sr} /{ }^{86} \mathrm{Sr}$ ratios of successive flows and their concentrations of $\mathrm{SiO}_{2}, \mathrm{FeO}$ (total iron), $\mathrm{Na}_{2} \mathrm{O}, \mathrm{K}_{2} \mathrm{O}, \mathrm{P}_{2} \mathrm{O}_{5}, \mathrm{Rb}$ and $\mathrm{Sr}$ decrease in ascending stratigraphic sequence while the concentrations of $\mathrm{TiO}_{2}, \mathrm{Al}_{2} \mathrm{O}_{3}, \mathrm{MgO}, \mathrm{CaO}$ and $\mathrm{MnO}$ increase upward. The initial ${ }^{87} \mathrm{Sr} /{ }^{86} \mathrm{Sr}$ ratios of the flows show a strong positive correlation with the strontium concentration. Similar correlations are observed between the initial ${ }^{87} \mathrm{Sr} /{ }^{86} \mathrm{Sr}$ ratios and all of the major oxide components. These relationships are incompatible with the hypothesis that these flows are the products of crystal fractionation of a magma at depth under closed-system conditions. It is suggested that the flows resulted from the hybridization of a normal tholeiite basalt magma by assimilation of varying amounts of granitic rocks in the Precambrian basement which underlies the entire Transantarctic Mountain chain.

Mixtures of two components having different ${ }^{87} \mathrm{Sr} /{ }^{86} \mathrm{Sr}$ ratios and differing strontium concentrations are related to each other by hyperbolic mixing equation. Such an equation was fitted by least squares regression of data points to a straight line in coordinates of initial ${ }^{87} \mathrm{Sr} /{ }^{86} \mathrm{Sr}$ and the reciprocals of the concentrations of strontium. This equation and plots of strontium versus other oxides were then used to estimate the chemical composition of the parent basalt magma and of the granitic contaminant by substituting reasonable estimates of their ${ }^{87} \mathrm{Sr} /{ }^{86} \mathrm{Sr}$ ratios. The chemical composition of the parent basalt $\left({ }^{87} \mathrm{Sr} /{ }^{86} \mathrm{Sr}=0.706\right)$ is generally compatible with that of average continental tholeiite, but is distinctive by having a low concentration of strontium (117 ppm). The chemical composition of the contaminant $\left({ }^{87} \mathrm{Sr} /{ }^{86} \mathrm{Sr}=0.720\right)$ is enriched in strontium $(173 \mathrm{ppm}), \mathrm{SiO}_{2}, \mathrm{FeO}$ (total iron) and the alkalies but is depleted in $\mathrm{Al}_{2} \mathrm{O}_{3}, \mathrm{MgO}$ and $\mathrm{CaO}$. The data for strontium indicate that the lava flows on Storm Peak contain between 20 and $40 \%$ of this granitic contaminant. The contamination of basalt magma is not a local event but is characteristic of the Jurassic. basalt flows and diabase sills throughout the Transantarctic Mountains and in Tasmania.

\footnotetext{
* Laboratory for Isotope Geology and Geochemistry, Contribution No. 33.

** Department of Geology and Mineralogy, University of Michigan, Ann Arbor, Michigan 48104.

*** Department of Geology, University of Georgia, Georgia 30601. 


\section{Introduction}

The Queen Alexandra Range of the Transantarctic Mountains is located west of the Beardmore Glacier between latitudes $83-85^{\circ} \mathrm{S}$ and longitudes $160-170^{\circ} \mathrm{E}$ as shown in Fig. 1. The geology of this range has been described by Barret (1972) and by other geologists referred to by him. In general, the Queen Alexandra Range consist of a basement composed of folded and metamorphosed sedimentary rocks of Precambrian age intruded by granitic rocks of Ordovician age. This basement complex is overlain by essentially flat-lying clastic sedimentary rocks of the Beacon Supergroup ranging in age from Devonian (?) to Late Triassic. The rocks of the Triassic system which consist in part of volcanic sandstones, tuffs and pyroclastic breccias, have been subdivided into the Fremouw, Falla, and the Prebble Formation, in ascending order. A suite of tuffs from the Falla Formation was dated by the whole-rock Rb-Sr method and was found to be $190 \pm 9$ million years old (Faure and Hill, 1973). The Beacon Supergroup is overlain by the Kirkpatrick Basalt flows of the Ferrar Group which is Jurassic in age. The Ferrar Group also contains diabase sills referred to as the Ferrar Dolerite. In the area of the Beardmore Glacier the Kirkpatrick Basalt attains a thickness of more than $600 \mathrm{~m}$, while the Ferrar Dolerite sills which intrude rocks of the Beacon Supergroup have a cumulative thickness of about $1000 \mathrm{~m}$ (Barret and Elliot, 1972).

The rocks of the Kirkpatrick Basalt and the related Ferrar Dolerite represent a distinctive petrologic province within the Transantarctic Mountains which extends from northern Victoria Land (Gair, 1967) to the Dufek Massif in the Pensacola Mountains (Ford and Boyd, 1968), a distance of about 2700 kilometers. The Mesozoic dolerites of Tasmania probably also belong to this petrologic province (McDougall, 1962; Heier et al., 1965). The petrography and chemical composition of Ferrar Dolerite sills in the "dry valley" region of southern Victoria Land of Antarctica have been studied by Gunn $(1962,1965,1966)$ and by Hamilton (1965).

The anomalous character of the Jurassic basalts and diabases of Tasmania and Antarctica was first revealed by the work of Heier et al. (1965) and Compston et al. (1968). They reported that these rocks have high initial $\mathrm{Sr}^{87} / \mathrm{Sr}^{86}$ ratios (about 0.712 ) and low $\mathrm{K} / \mathrm{Rb}$ ratios $(210-240)$ compared to continental tholeiites elsewhere. They reported unexpectedly high $\mathrm{Th} / \mathrm{K}$ and $\mathrm{U} / \mathrm{K}$ ratios, all of which suggests that these basaltic rocks had an unusual petrogenesis and may have been modified in some way by interaction with granitic rocks of the continental crust. Faure et al. (1972) subsequently demonstrated that basaltic rocks of the Ferrar Group in the Transantarctic Mountains from northern Victoria Land to the Dufek Massif all have anomalously high initial $\mathrm{Sr}^{87} / \mathrm{Sr}^{86}$ ratios of about 0.712 and low $\mathrm{K} / \mathrm{Rb}$ ratios of about 240 . Moreover, they observed remarkable correlations between the initial $\mathrm{Sr}^{87} / \mathrm{Sr}^{86}$ ratios and the concentrations of several major elements. These correlations were particularly striking for a suite of seven basalt specimens from Storm Peak of the Marshall Mountains in the Queen Alexandra Range.

We now report determinations of initial $\mathrm{Sr}^{87} / \mathrm{Sr}^{86}$ ratios and major element concentrations for a larger suite of twenty samples from Storm Peak. The objective of this study is to interpret these data in order to derive new insight into the petrogenesis of these unusual rocks (Bowman et al., 1973). 


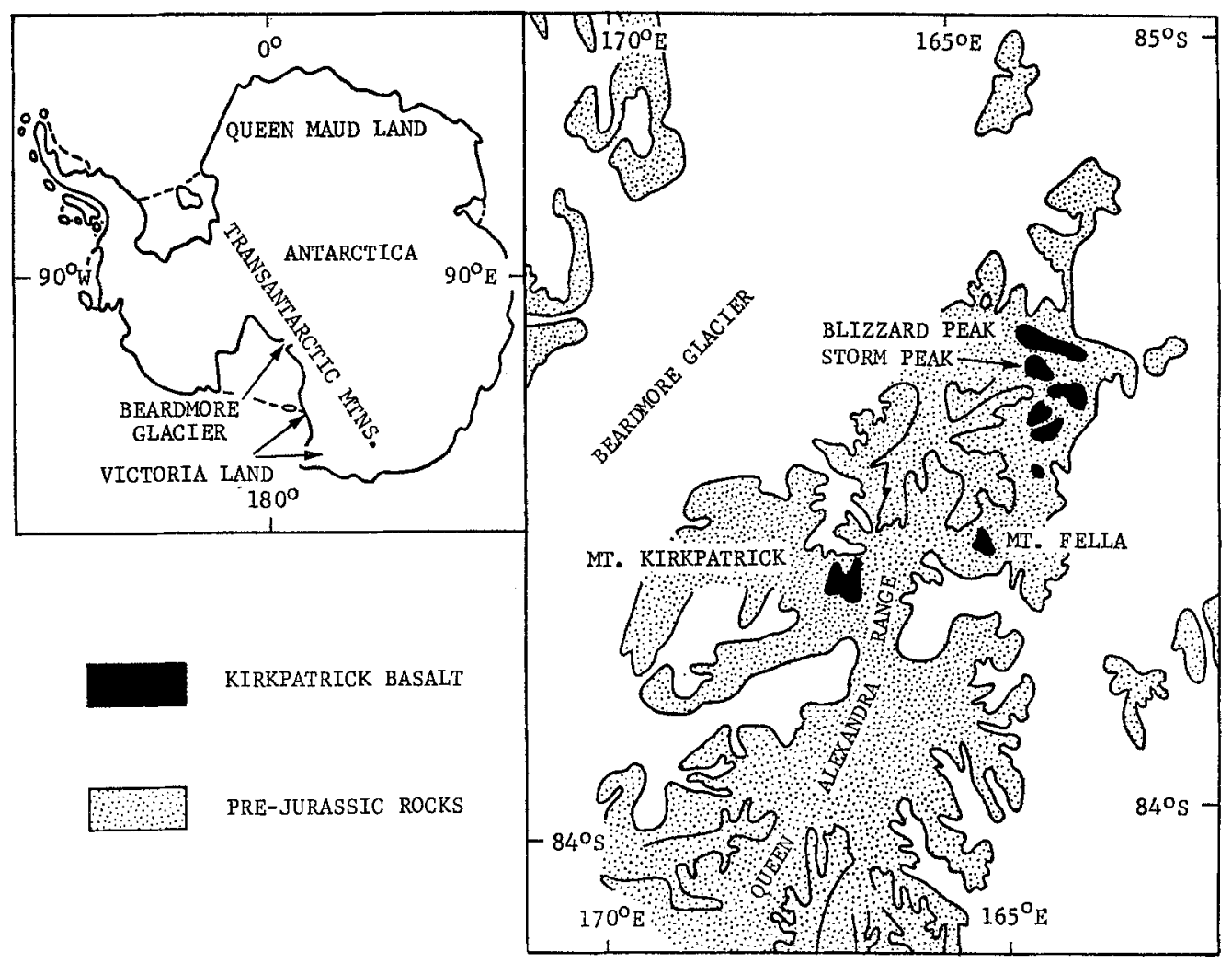

Fig. 1. Index map of Antarctica and generalized geological map of the Queen Alexandra Range near the Beardmore Glacier in the Transantarctic Mountains.

\section{Geology of Storm Peak}

Storm Peak is located at $84^{\circ} 35^{\prime} \mathrm{S}$ and $163^{\circ} 55^{\prime} \mathrm{E}$ in the Marshall Mountains of the Queen Alexandra Range (Fig. 1). It is capped by twelve basalt flows whose total thickness is about $525 \mathrm{~m}$. The stratigraphy and petrography of the Kirkpatrick Basalt in the Beardmore Glacier region have been described by Elliot $(1970,1972)$.

The age of the flows at Storm Peak is indicated by three whole rock K-Ar dates which range from $163-179 \mathrm{~m} . \mathrm{y}$. and average $171 \pm 8 \mathrm{~m} . \mathrm{y}$. (Elliot, 1970). In addition, Elliot and Tasch (1967) described conchostracans assignable to Cyzicus Lioestheria sp. from sedimentary rocks interbedded with basalt flows at Blizzard Peak a few miles south of Storm Peak. Moreover, Elliot collected a suite of freshwater fish from a thin bed of inter-flow sediment on Storm Peak which were subsequently identified by Schaeffer (1972) as a new genus and species Oreochima ellioti of the pholidophoriform family Archaemaenidae. Both the conchostracans and the fossil fish indicate a Jurassic age for the KirkpatrickBasalt which is consistent also with the $\mathrm{K}$-Ar dates mentioned above and summarized by Elliot (1970). 

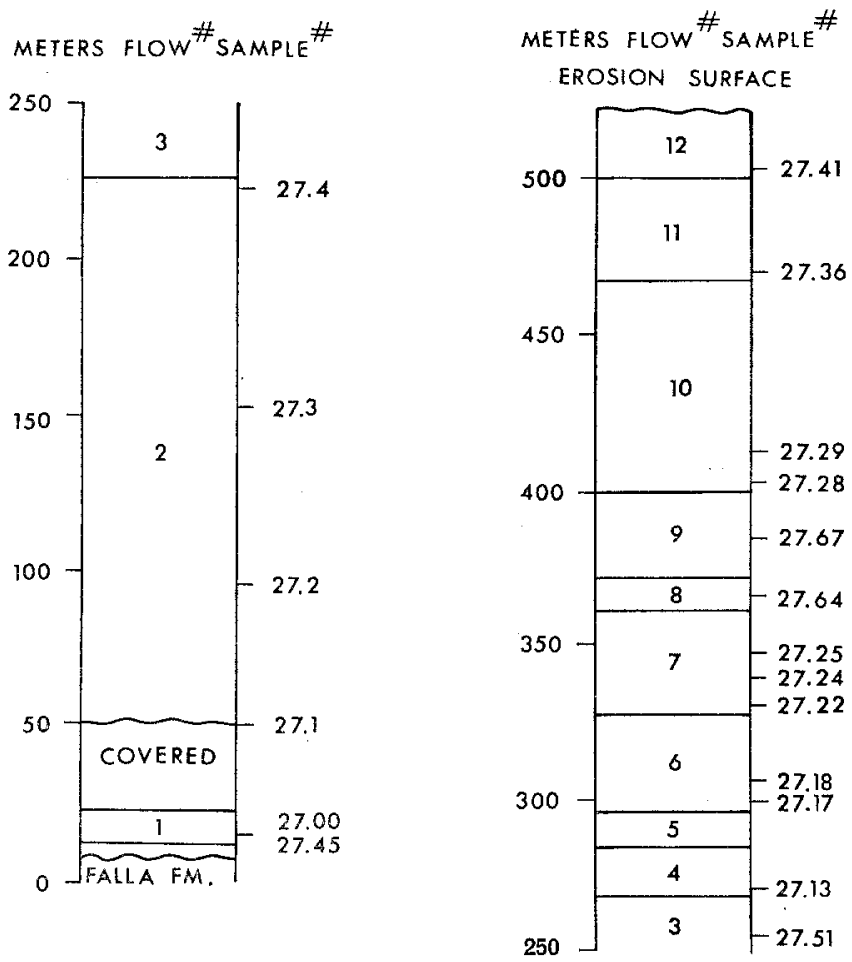

Fig. 2. Geologic column of lava flows of the Kirkpatrick Basalt on Storm Peak in the Queen Alexandra Range and stratigraphic location of samples used in this study

The stratigraphy of the twelve flows on Storm Peak is illustrated in Fig. 2. The individual flows range in thickness from $11-175 \mathrm{~m}$. They are separated by thin interbeds of acidic tuff and siliceous mudstone. The flows have vesicular tops and appear to have been extruded subaerially. The rocks are fine grained with intergranular or intersertal textures, except for coarse-grained varieties which have diabasic textures. The essential minerals are labradorite and pyroxene which occur as microphenocrysts in a matrix of slender labradorite laths, pyroxene grains, reddish brown iron oxides and irresolvable crystalline material of probable quartzo-feldspathic composition. Glass, devitrified glass, and quartz-feldspar mesostasis together make up from $15 \%$ to more than $60 \%$ of the rocks. Normative mineral compositions calculated by Elliot $(1970,1972)$ include quartz and orthoclase and thus are not typical of basalt. Nevertheless, these rocks have been classified as tholeiites on the basis of the mineralogy of the microphenocrysts. It is believed that excess silica and potassium are associated with the glassy or devitrified matrix. Elliot (1972) noted the low $\mathrm{MgO}$ content of these rocks and suggested that it is a consequence of segregation of early-formed orthopyroxene in the magma chamber leaving a residual silica-rich and magnesium-poor liquid which was subsequently extruded. 
Table 1. Isotopic composition of strontium and concentrations of rubidium and strontium, Kirkpatrick Basalt, Storm Peak, Antarctica

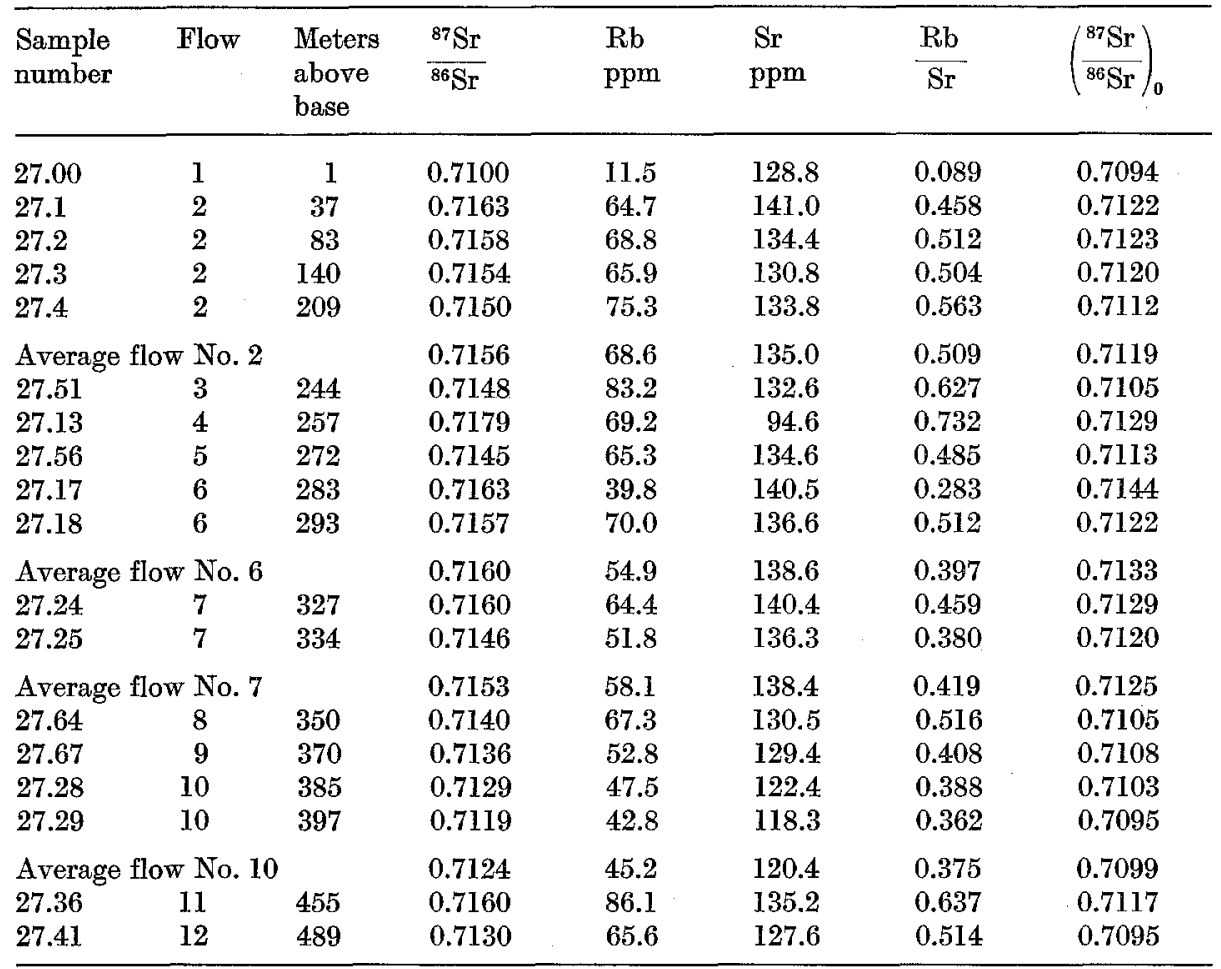

Rubidium and strontium were determined either by $\mathrm{X}$-ray fluorescence or by isotope dilution using calibrated spikes enriched in ${ }^{87} \mathrm{Rb}$ and ${ }^{86} \mathrm{Sr}$, respectively. The average ${ }^{87} \mathrm{Sr} /{ }^{86} \mathrm{Sr}$ ratio for the Eimer and Amend Sr-isotope standard was $0.7081 \pm 0.0005(1 \sigma)$. All ${ }^{87} \mathrm{Sr} /{ }^{86} \mathrm{Sr}$ ratios have been corrected for isotope fractionation to a standard value of ${ }^{86} \mathrm{Sr} / 88 \mathrm{Sr}=0.1194$. The initial ${ }^{87} \mathrm{Sr} /{ }^{86} \mathrm{Sr}$ ratios were calculated assuming an age of $170 \mathrm{~m} . \mathrm{y}$. for the flows.

\section{Isotopic and Chemical Stratigraphy}

The ${ }^{87} \mathrm{Sr} / 86 \mathrm{Sr}$ ratios and concentrations of rubidium and strontium of eighteen basalt samples from Storm Peak are presented in Table 1. Details of the analytical procedures can be found in Bowman (1971) and Hill (1969). The initial ${ }^{87} \mathrm{Sr} /{ }^{86} \mathrm{Sr}$ ratios of each specimen have been calculated by correcting the measured values for the decay of ${ }^{87} \mathrm{Rb}$ since these rocks crystallized 170 million years ago. The initial ${ }^{87} \mathrm{Sr} /{ }^{86} \mathrm{Sr}$ of the flows range from 0.7094 to 0.7133 and average 0.7112 土 0.0013 . Basaltic rocks generally have significantly lower ${ }^{87} \mathrm{Sr} /{ }^{86} \mathrm{Sr}$ ratios of about $0.704 \pm 0.002$ (Faure and Powell, 1972). The average concentrations of rubidium and strontium of the flows are $60.6 \pm 19.4$ and $128.8 \pm 11.9 \mathrm{ppm}$, respectively. The strontium concentrations are unusually low when compared to quartznormative basalt which contain $471 \mathrm{ppm}$ strontium on the average (Prinz, 1967). The rubidium content of the flows on Storm Peak, on the other hand, is nearly twice the average of $33 \mathrm{ppm}$ reported by Prinz (1967) for quartz-normative basalts. Consequently, the Rb/Sr of the flows on Storm Peak have an unusually 
Table 2. Chemical compositions of the flows on Storm

\begin{tabular}{|c|c|c|c|c|c|c|c|}
\hline Flow & 1 & 2 & 3 & 4 & 5 & 6 & 7 \\
\hline $\mathrm{SiO}_{2}$ & 53.14 & 57.98 & 57.51 & 57.30 & 56.51 & 57.91 & 57.38 \\
\hline $\mathrm{TiO}_{2}$ & 0.63 & 1.44 & 1.40 & 1.43 & 1.48 & 1.47 & 0.50 \\
\hline $\mathrm{Al}_{2} \mathrm{O}_{3}$ & 13.98 & 12.23 & 12.90 & 12.84 & 13.02 & 12.30 & 13.78 \\
\hline $\mathrm{Fe}_{2} \mathrm{O}_{3}$ & 4.40 & 3.26 & 4.13 & 6.91 & 4.00 & 2.77 & 6.08 \\
\hline $\mathrm{FeO}$ & 5.11 & 8.93 & 7.98 & 6.28 & 8.23 & 9.37 & 5.88 \\
\hline Total FeO & 9.07 & 11.86 & 11.70 & 12.50 & 11.83 & 11.86 & 11.35 \\
\hline MnO & 0.36 & 0.32 & 0.17 & 0.17 & 0.19 & 0.32 & 0.17 \\
\hline $\mathrm{MgO}$ & 7.14 & 2.53 & 2.67 & 2.75 & 3.00 & 2.97 & 2.75 \\
\hline $\mathrm{CaO}$ & 9.67 & 7.09 & 7.66 & 6.33 & 8.42 & 7.41 & 6.93 \\
\hline $\mathrm{Na}_{2} \mathrm{O}$ & 2.15 & 2.20 & 2.62 & 2.32 & 2.36 & 2.08 & 2.25 \\
\hline $\mathrm{K}_{2} \mathrm{O}$ & 0.49 & 1.52 & 1.08 & 1.69 & 0.92 & 1.61 & 1.71 \\
\hline $\mathrm{P}_{2} \mathrm{O}_{5}$ & 0.07 & 0.18 & 0.17 & 0.17 & 0.16 & 0.14 & 0.18 \\
\hline $\mathrm{H}_{2} \mathrm{O}^{+}$ & 2.12 & 1.84 & 1.65 & 1.79 & 1.85 & 1.59 & 1.32 \\
\hline $\mathbf{R b}, \mathrm{ppm}$ & 11.5 & 68.6 & 83.2 & 69.2 & 65.3 & 54.9 & 58.1 \\
\hline $\mathrm{Sr}, \mathrm{ppm}$ & 128.8 & 135.0 & 132.6 & 94.6 & 134.6 & 138.6 & 138.4 \\
\hline$\left(\frac{87}{86} \mathrm{Sr}\right)_{0}$ & 0.7094 & 0.7119 & 0.7105 & 0.7129 & 0.7113 & 0.7133 & 0.7125 \\
\hline $\mathbf{K} / \mathbf{R b}$ & 354 & 182 & 108 & 203 & 117 & 243 & 244 \\
\hline
\end{tabular}

$\mathrm{A}=$ average of all flows; $\mathrm{B}=$ average continental tholeiite (Manson, 1967); $\mathrm{C}=$ average oceanic

a Concentrations of $\mathrm{TiO}_{2}, \mathrm{Al}_{2} \mathrm{O}_{3}, \mathrm{Fe}_{2} \mathrm{O}_{3}, \mathrm{FeO}, \mathrm{MnO}, \mathrm{MgO}$ and $\mathrm{P}_{2} \mathrm{O}_{5}$ from Elliot $(1970,1972)$. those given by Elliot.

high average of 0.47 compared to 0.070 for average basalt. The only exception is flow No. 1 whose $\mathrm{Rb} / \mathrm{Sr}$ ratio is 0.089 primarily because of its low rubidium concentration of $11.5 \mathrm{ppm}$. This flow also differs in many other respects, although it too has an anomalously high initial ${ }^{87} \mathrm{Sr} /{ }^{86} \mathrm{Sr}$ ratio.

The concentrations of the major oxide components in each of the twelve flows are listed in Table 2 together with the average concentrations of rubidium, strontium and the initial ${ }^{87} \mathrm{Sr} /{ }^{86} \mathrm{Sr}$ ratios. A comparison of the average composition of the flows on Storm Peak (column A) with those of continental and oceanic tholeiites (columns B and C) discloses several significant discrepancies. The basalt from Storm Peak has higher concentrations of $\mathrm{SiO}_{2}(56.60 \%), \mathrm{K}_{2} \mathrm{O}(1.29 \%)$, total iron as $\mathrm{FeO}(11.57 \%)$ and $\mathrm{H}_{2} \mathrm{O}+(1.62 \%)$ while the concentrations of $\mathrm{Al}_{3} \mathrm{O}_{2}(12.92 \%), \mathrm{MgO}(3.44 \%)$ and $\mathrm{CaO}(7.91 \%)$ are significantly lower. The $\mathrm{TiO}_{2}$ content of the flows $(1.28 \%)$ is comparable to that of continental tholeiites, but it is only about one half that of oceanic tholeiites. On the other hand, the low strontium content of these basalts is similar to that of oceanic tholeiites. The $\mathrm{K} / \mathrm{Rb}$ ratios of the flows range from 100 (No. 11) to 354 (No. 1) and average 200. This is well below the average of $\mathbf{3 4 9}$ for quartz-normative basalts (Prinz, $1967)$ and is similar to the $\mathrm{K} / \mathrm{Rb}$ ratios of typical granitic rocks.

A schematic plot of the initial ${ }^{87} \mathrm{Sr} /{ }^{86} \mathrm{Sr}$ ratios and of the other chemical components versus successive flow numbers is presented in Fig. 3. It is evident that three major discontinuities are revealed which have been used to divide this sequence of flows into four sets numbered consecutively from I to IV from the bottom up. The initial ${ }^{87} \mathrm{Sr} /{ }^{86} \mathrm{Sr}$ ratios of successive flows in a given set decrease in ascending 
Peak, Queen Alexandra Range, in weight percenta

\begin{tabular}{rrrrrrrr}
\hline 8 & \multicolumn{1}{c}{9} & \multicolumn{1}{c}{10} & \multicolumn{1}{c}{11} & \multicolumn{1}{c}{12} & \multicolumn{1}{c}{$\mathrm{A}$} & \multicolumn{1}{c}{$\mathrm{B}$} & \multicolumn{1}{c}{$\mathrm{C}$} \\
\hline 56.27 & 56.16 & 55.16 & 57.85 & 56.01 & 56.60 & 51.5 & 49.3 \\
1.40 & 1.27 & 1.00 & 1.05 & 2.33 & 1.28 & 1.2 & 2.4 \\
13.40 & 13.38 & 13.49 & 12.24 & 11.56 & 12.92 & 16.3 & 14.6 \\
2.56 & 4.50 & 5.05 & 4.75 & 5.56 & 4.50 & 2.8 & 3.2 \\
18.65 & 6.48 & 5.21 & 8.41 & 9.75 & 7.52 & 7.9 & 8.5 \\
0.95 & 10.53 & 9.75 & 12.68 & 14.75 & 11.57 & 10.4 & 11.4 \\
0.19 & 0.17 & 0.18 & 0.22 & 0.23 & 0.22 & 0.17 & 0.17 \\
3.51 & 3.98 & 5.21 & 2.72 & 2.12 & 3.44 & 5.9 & 7.4 \\
8.59 & 8.79 & 9.44 & 7.45 & 7.15 & 7.91 & 9.8 & 10.6 \\
2.52 & 2.26 & 2.12 & 2.51 & 2.41 & 2.29 & 2.5 & 2.2 \\
1.01 & 1.51 & 1.41 & 1.04 & 1.77 & 1.29 & 0.86 & 0.53 \\
0.16 & 0.14 & 0.12 & 0.20 & 0.26 & 0.16 & 0.21 & 0.26 \\
1.76 & 1.30 & 1.36 & 1.55 & 1.29 & 1.62 & 0.81 & 0.79 \\
67.3 & 52.8 & 45.2 & 86.1 & 65.6 & 60.6 & & \\
130.5 & 129.4 & 120.4 & 135.2 & 127.6 & 128.8 & & \\
0.7105 & 0.7108 & 0.7099 & 0.7117 & 0.7095 & 0.7112 & & \\
125 & 237 & 259 & 100 & 224 & 200 & & \\
\hline
\end{tabular}

tholeiite (Manson, 1967).

Concentrations of $\mathrm{SiO}_{2}, \mathrm{CaO}, \mathrm{K}_{2} \mathrm{O}$ and $\mathrm{Na}_{2} \mathrm{O}$ have been re-determined and averaged with

stratigraphic order. The lowest (oldest) flow in a typical set such as III has the highest initial ${ }^{87} \mathrm{Sr} /{ }^{86} \mathrm{Sr}$ ratio. Succeding younger flows have lower ratios and the uppermost flow has the lowest initial ${ }^{87} \mathrm{Sr} /{ }^{86} \mathrm{Sr}$ ratio of the set.

Fig. 3 also contains similar diagrams for the concentrations of all of the major oxides, including strontium. It can be seen that all of the components show this stratigraphic variation and that the four sets of flows have sequentially related chemical properties. In general, the concentrations of $\mathrm{SiO}_{2}, \mathrm{FeO}, \mathrm{Na}_{2} \mathrm{O}, \mathrm{K}_{2} \mathrm{O}$, $\mathrm{P}_{3} \mathrm{O}_{5}$ and $\mathrm{Sr}$ decrease upward stratigraphically in each set while the concentrations of $\mathrm{TiO}_{2}, \mathrm{Al}_{2} \mathrm{O}_{3}, \mathrm{MgO}, \mathrm{CaO}$ and $\mathrm{MnO}$ increase.

Set I consists of only one flow (No. 1) which differs markedly from all the others on Storm Peak. It has the lowest concentrations of $\mathrm{SiO}_{2}$, $\mathrm{TiO}, \mathrm{FeO}, \mathrm{K}_{2} \mathrm{O}, \mathrm{P}_{2} \mathrm{O}_{5}$ and $\mathrm{Rb}$ and the highest concentrations of $\mathrm{Al}_{2} \mathrm{O}_{3}, \mathrm{MnO}, \mathrm{MgO}$ and $\mathrm{CaO}$. It also has the lowest initial ${ }^{87} \mathrm{Sr} /{ }^{86} \mathrm{Sr}$ ratio and might be regarded as the last of a more extensive set of flows which are not present at this location.

Set II includes flows 2, 3, 4 and 5. They exhibit the systematic stratigraphic variations of the oxide concentrations and initial ${ }^{87} \mathrm{Sr} /{ }^{86} \mathrm{Sr}$ ratios noted before. Straight lines have been fitted to the data points to provide a reference by means of which departures from the pattern can be recognized. With some notable exceptions, the fit of the data to these reference lines is remarkably good. Flow No. 4 is anomalous in several respects. Its initial ${ }^{87} \mathrm{Sr} /{ }^{86} \mathrm{Sr}$ ratio $(0.7129)$ is too high while its concentrations of calcium and strontium are too low. All three parameters were determined in duplicate with reproducible results. This flow also has the highest $\mathrm{Fe}_{2} \mathrm{O}_{3} / \mathrm{FeO}$ ratio of any of the samples from Storm Peak. This 



Fig. 3. Diagrammatic representation of the stratigraphic variation of the initial ${ }^{87} \mathrm{Sr} /{ }^{86} \mathrm{Sr}$ ratios and of the major oxide components of the flows. Dashed reference lines were drawn through the data points to emphasize the systematic variations on the basis of which four eruptive episodes were identified by Roman numerals. Certain data points were shifted to the reference lines in the subsequent quantitative analysis of the data as indicated by horizontal arrows

suggests that the sample (27.13) representing this flow has been altered, perhaps by chemical weathering. In several instances the oxide concentrations and initial ${ }^{87} \mathrm{Sr} /{ }^{86} \mathrm{Sr}$ ratios of flows in Sets II and III have been adjusted by shifting them to the reference lines for the purpose of a quantitative treatment of the data 
described later. This is indicated by arrows pointing toward the reference line. In Set II we have shifted the initial ${ }^{87} \mathrm{Sr} /{ }^{86} \mathrm{Sr}$ ratios of flows 3 and 4 , the $\mathrm{TiO}_{2}$ concentration of flow 2 and the strontium and calcium contents of flow 4 . The concentrations of iron expressed as $\mathrm{FeO}$ in the flows of Set II are so irregular that no reference line was drawn.

Set III consists of flows $6,7,8,9$ and 10 most of which fit closely to the reference lines. The data points that were shifted are marked by arrows as before. Set IV contains only flows 11 and 12. Flow No. 12 is represented by sample 27.41 which may be severely altered. It seems to be enriched in $\mathrm{TiO}_{2}, \mathrm{FeO}$ and $\mathrm{K}_{2} \mathrm{O}$ and is depleted in $\mathrm{Al}_{2} \mathrm{O}_{3}, \mathrm{MgO}, \mathrm{CaO}$ and $\mathrm{P}_{2} \mathrm{O}_{5}$. No reference line was drawn for Set IV and flow 12 was omitted in most of the following quantitative treatment of the data. However, the chemical composition of flow 11 is consistent with the assumption that it is the first flow in a renewed cycle of volcanic eruption which may have included a series of flows only two of which are preserved.

The stratigraphic variation of chemical and isotopic parameters leads us to conclude that the lava flows preserved on Storm Peak were extruded during four eruptive cycles. The systematic variation of these parameters within each set of flows reflects the operation of a peculiar petrogenetic process which resulted in the initial extrusion of flows enriched in silica, alkali metals and total iron followed by flows which had progressively lower concentrations of silica, allkali metals and iron but contained more $\mathrm{CaO}, \mathrm{MgO}$ and $\mathrm{Al}_{2} \mathrm{O}_{3}$. Such chemical differentiation of lava flows is commonly attributed to progressive crystal fractionation of the magma at depth. However, it is well known that the isotopes of strontium are not measurably fractionated by chemical or physical processes occurring in nature. In any case, a correction is routinely applied to all measured ${ }^{87} \mathrm{Sr} /{ }^{86} \mathrm{Sr}$ ratios which eliminates the effects of both intrumental as well as natural isotope fractionation (Faure and Powell, 1972). For this reason, the stratigraphic variation of the initial ${ }^{87} \mathrm{Sr} /{ }^{86} \mathrm{Sr}$ ratios of the basalt flows on Storm Peak cannot be the result of crystal fractionation of magma under closed-system conditions. This point is reinforced by Fig. $4 \mathrm{~A}$ which illustrates a strong positive correlation between the initial ${ }^{87} \mathrm{Sr} /{ }^{86} \mathrm{Sr}$ ratios of the flows and their strontium concentrations. This relationship is incompatible with fractional crystallization of a homogeneous magma and is strong evidence that these flows were produced by a different petrogenetic process.

\section{Petrogenesis of the Kirkpatrick Basalt}

The lava flows on Storm Peak, which we believe to be typical representatives of the Kirkpatrick Basalt in the Transantarctic Mountains, may have been formed by one of two possible processes: 1. Basalt Magma was generated in the lower crust or in the upper mantle by partial melting of rocks having a range of $\mathrm{Rb} / \mathrm{Sr}$ ratios and chemical compositions, in such a way that successive lava flows had systematically decreasing $\mathrm{Sr}^{87} / \mathrm{Sr}^{86}$ ratios and changing chemical composition as required by the evidence in Fig. 3. 2. A parent magma of basaltic composition interacted with old granitic rocks of the continental crust in such a way that it became isotopically and chemically heterogeneous. Batches of magma were then expelled from the reservoir starting with magma at the top of the chamber which 
was presumably more strongly enriched in the contaminants than lower portions from which magma was withdrawn later. A possible variation of this process might be one in which batches of magma were expelled at intervals and became contaminated by interactions with rocks exposed in the volcanic vent such that the first flow to be produced had a higher $\mathrm{Sr}^{87} / \mathrm{Sr}^{86}$ ratio and strontium concentration than subsequent flows.

The derivation of lava flows by progressive melting of source rocks having different $\mathrm{Rb} / \mathrm{Sr}$ ratios seems to us to be very unlikely because of the regional similarity of the basaltic rocks in this large petrologic province (Faure et al., 1972). A third, but very remote, possibility is that the high $\mathrm{Sr}^{87} / \mathrm{Sr}^{86}$ ratios of the flows resulted from decay of $\mathrm{Rb}^{87}$ to ${ }^{87} \mathrm{Sr}$ in a chemically-zoned magma chamber. This is very unlikely because unreasonably long periods of time would be required to raise the $\mathrm{Sr}^{87} / \mathrm{Sr}^{86}$ ratios of the magma to the observed initial ratios. The average $\mathrm{Rb} / \mathrm{Sr}$ ratio of the flows is 0.47 and, if the $\mathrm{Sr}^{87} / \mathrm{Sr}^{86}$ ratio was initially 0.704 , it would take about 360 million years for the $\mathrm{Sr}^{87} / \mathrm{Sr}^{86}$ ratio to increase to 0.711 . These considerations suggest to us that the isotopic compositions of strontium of these flows and their chemical compositions are the result of interactions of a basaltic parent magma with the rocks of the continental crust through which the lava flows were extruded.

The relationship between the initial $\mathrm{Sr}^{87} / \mathrm{Sr}^{86}$ ratios and strontium concentrations shown in Fig. 4A can be explained by additions of varying amounts of a contaminant having a high $\mathrm{Sr}^{87} / \mathrm{Sr}^{86}$ ratio and high strontium concentration to a basalt magma containing strontium with a low $\mathrm{Sr}^{87} / \mathrm{Sr}^{86}$ ratio and having a lower strontium content. The mechanism by which these additions occurred must remain unspecified for the time being because the data do not disclose it.

Let us consider therefore a hypothetical process by means of which two components of differing strontium concentrations and differing $\mathrm{Sr}^{87} / \mathrm{Sr}^{86}$ ratios are mixed in varying proportions. Following the example of Pushkar et al. (1972), we define a parameter $P$ as the weight of the contaminant per unit weight of uncontaminated basalt magma. The concentrations of strontium, or of any other element, in such mixtures is given by:

where

$$
X_{M}=\frac{1}{P+1} X_{B}+\frac{P}{P+1} X_{C}
$$

$X_{M}, X_{B}, X_{C}=$ concentrations of element $X$ in the mixture $(M)$, the basalt magma $(B)$, and the contaminant $(C)$, respectively. The $\mathrm{Sr}^{87} / \mathrm{Sr}^{86}$ ratios of the mixtures are:

$$
\left(\frac{{ }^{87} \mathrm{Sr}}{{ }^{86} \mathrm{Sr}}\right)_{M}=\frac{\mathrm{Sr}_{B}}{\mathrm{Sr}_{B}+P \mathrm{Sr}_{C}}\left(\frac{{ }^{87} \mathrm{Sr}}{{ }^{86} \mathrm{Sr}}\right)_{B}+\frac{P \mathrm{Sr}_{C}}{\mathrm{Sr}_{B}+P \mathrm{Sr}_{C}}\left(\frac{{ }^{87} \mathrm{Sr}}{{ }^{86} \mathrm{Sr}}\right)_{C}
$$

In the derivation of Eq. (2) it is assumed that the atomic weights of strontium and the isotopic abundances of $\mathrm{Sr}^{86}$ of the basalt magma and the contaminant are identical. These two assumptions introduce a negligible error, provided that the $\mathrm{Sr}^{87} / \mathrm{Sr}^{86}$ ratio of the contaminant is not a large number. Eqs. (1) and (2) define the concentration $\left(\mathrm{Sr}_{M}\right)$ and the isotopic composition $\left({ }^{87} \mathrm{Sr} /{ }^{86} \mathrm{Sr}\right)_{M}$ of mixtures of two end members combined in varying proportions indicated by parameter $P$. The two equations can be merged by eliminating $P$ : 


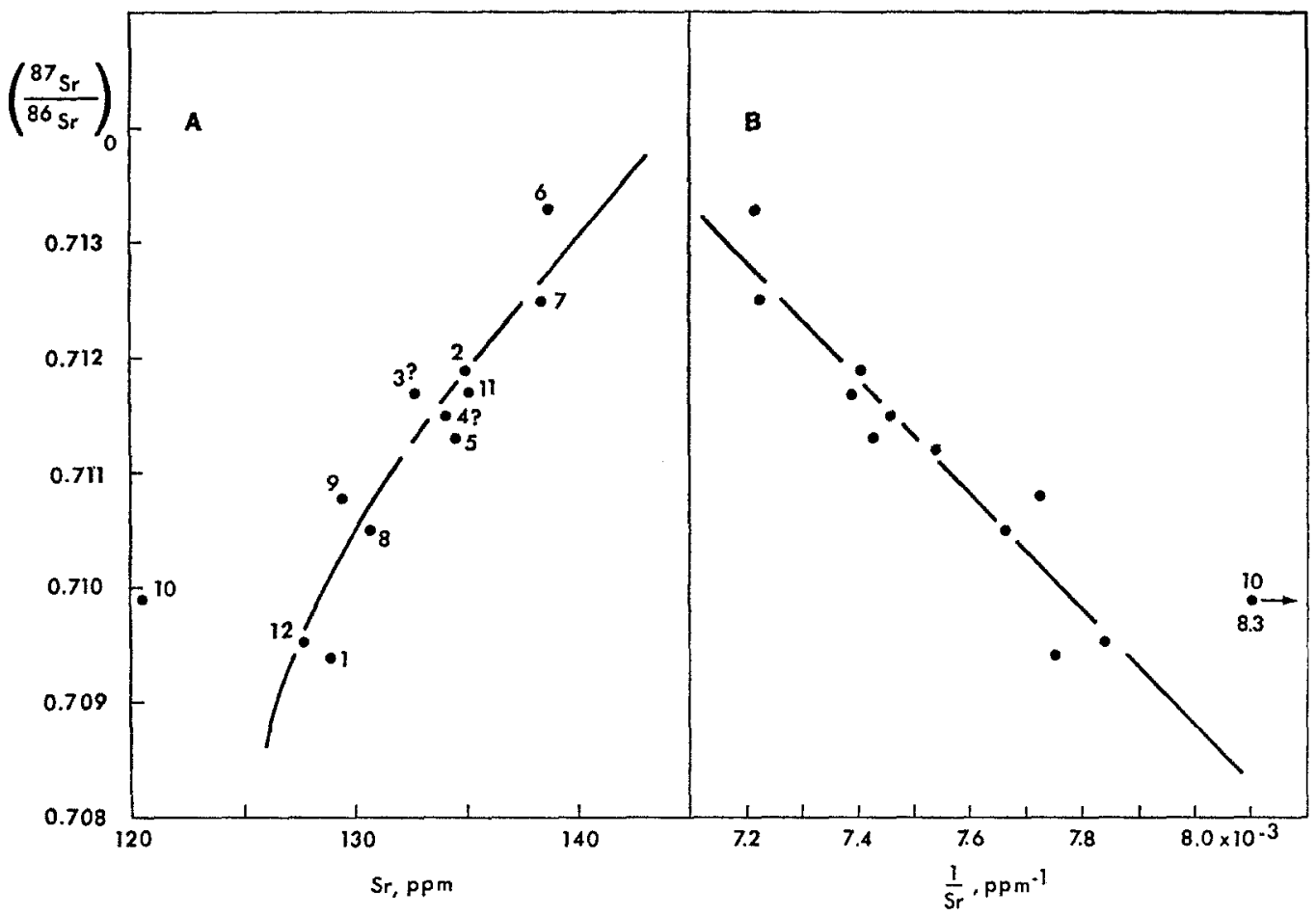

Fig. 4. A Plot of initial ${ }^{87} \mathrm{Sr} /{ }^{86} \mathrm{Sr}$ ratios of the lava flows versus their strontium concentration. B Plot of initial ${ }^{87} \mathrm{Sr} /{ }^{86} \mathrm{Sr}$ ratios of the lava flows versus the reciprocals of the strontium concentrations. The equation of the straight line in $\mathrm{B}$ was determined by least-squares regression (see text) and was plotted in A as a hyperbola. The numbers associated with the data points in part $A$ identify the flows. The question marks indicate that the data have been adjusted to the reference lines drawn in Fig. 3

where:

$$
\left(\frac{{ }^{87} \mathrm{Sr}}{{ }^{86} \mathrm{Sr}}\right)_{M}=A+\frac{B}{\mathrm{Sr}_{M}}
$$

$$
\begin{aligned}
& A=\frac{\left(\frac{{ }^{87} \mathrm{Sr}}{{ }^{86} \mathrm{Sr}}\right)_{B} \mathrm{Sr}_{B}-\left(\frac{{ }^{87} \mathrm{Sr}}{{ }^{86} \mathrm{Sr}}\right)_{C} \mathrm{Sr}_{C}}{\mathrm{Sr}_{B}-\mathrm{Sr}_{C}} \\
& B=\frac{\mathrm{Sr}_{B} \mathrm{Sr}_{C}\left[\left(\frac{{ }^{87} \mathrm{Sr}}{{ }^{86} \mathrm{Sr}}\right)_{C}-\left(\frac{{ }^{87} \mathrm{Sr}}{{ }^{86} \mathrm{Sr}}\right)_{B}\right]}{\mathrm{Sr}_{B}-\mathrm{Sr}_{C}}
\end{aligned}
$$

Eq. (3) represents a hyperbola in coordinates of $\left({ }^{87} \mathrm{Sr} /{ }^{86} \mathrm{Sr}\right)_{M}$ and $\mathrm{Sr}_{M}$. It can also be treated as the equation of a straight line in the slope-intercept form in coordinates of $\left.{ }^{87} \mathrm{Sr} / \mathrm{Sr}^{86}\right)_{M}$ and $(1 / \mathrm{Sr})_{M}$, where $A$ is the intercept and $\mathrm{B}$ is the slope of the line.

We now derive an equation for the mixing hyperbola for the basalt flows on Storm Peak on the basis of the assumption that their initial ${ }^{87} \mathrm{Sr} /{ }^{86} \mathrm{Sr}$ ratios and strontium concentrations are the result of mixing of two components in varying 


proportions. For this purpose their initial ${ }^{87} \mathrm{Sr} /{ }^{86} \mathrm{Sr}$ ratios were plotted versus the reciprocals of their strontium concentrations in Fig. 4B. A straight line was fitted to the data points by least-squares regression. The equation of this line is:

$$
\left(\frac{{ }^{87} \mathrm{Sr}}{{ }^{86} \mathrm{Sr}}\right)_{M}=0.7492-5.0483\left(\frac{1}{\mathrm{Sr}_{M}}\right)
$$

The satisfactory fit of the data points to this line indicates that the isotopic composition and concentration of strontium of these flows are consistent with the two-component mixing model. Points can be scattered off the line either because of analytical errors or because the concentration and isotopic composition of strontium were changed subsequent to mixing. The validity of the mixing model rests on the assumption that the concentration of strontium in the contaminated basalt magma was not changed by fractional crystallization subsequent to mixing and that neither the concentrations nor the ${ }^{87} \mathrm{Sr} /{ }^{86} \mathrm{Sr}$ ratios of the flows were altered as a result of the deposition of secondary minerals or as a result of chemical weathering. It is unlikely that these conditions are satisfied by all of the flows with respect to all of the major oxides. Nevertheless, the strontium data seem to fit the mixing line reasonably well which suggests that in this case the ${ }^{87} \mathrm{Sr} /{ }^{86} \mathrm{Sr}$ ratios and strontium concentrations of the flows are adequately described by the mixing model. The only exception is flow 10 which scatters far off the line in Fig. 4B and was therefore omitted from the regression. This flow is represented by two samples (27.28 and 27.29 ) both of which have very similar concentrations of rubidium and strontium and ${ }^{87} \mathrm{Sr} /{ }^{86} \mathrm{Sr}$ ratios (Table 1). Therefore the deviation of this flow from the mixing line may be due to processes occurring after mixing had taken place and is probably not the result of analytical error. The line drawn in Fig. 4A is a segment of the mixing hyperbola whose equation was derived by the regression of the data points in Fig. 4B [Eq. (4)].

Similar correlations between the initial ${ }^{87} \mathrm{Sr} /{ }^{86} \mathrm{Sr}$ ratios of the flows and the concentrations of major oxides are illustrated in Fig. 5. It is apparent that significant positive and negative correlations exist which reinforce our previous statement that these flows cannot be the products of fractional crystallization of magma at depth under closed-system conditions. The most unequivocal relationships are displayed by the flows of set III as indicated by straight lines drawn through these data points. Well-developed positive correlations with initial ${ }^{87} \mathrm{Sr} /{ }^{86} \mathrm{Sr}$ ratios are shown by $\mathrm{SiO}_{2}$, total iron as $\mathrm{FeO}, \mathrm{Na}_{2} \mathrm{O}$ and $\mathrm{K}_{2} \mathrm{O}$, while $\mathrm{TiO}_{2}$, $\mathrm{Al}_{2} \mathrm{O}_{3}, \mathrm{MgO}$ and $\mathrm{CaO}$ correlate negatively. The initial ${ }^{87} \mathrm{Sr} /{ }^{86} \mathrm{Sr}$ ratios and concentrations of major oxides of the flows in set II exhibit less variation than those of set III and appear to represent somewhat different mixing regimes. This is especially well shown for $\mathrm{SiO}_{2}, \mathrm{MgO}, \mathrm{CaO}$ and $\mathrm{Na}_{2} \mathrm{O}$ and is indicated in Fig. 5 by separate lines. Flow 11 of set IV tends to line up with the flows of set II. The parameters of flows 1 and 12 are quite erratic and generally do not fit the patterns established by the flows of either set II or IIT.

The concentrations of strontium of the hypothetical end members were estimated by means of equation 4 using reasonable estimates of their ${ }^{87} \mathrm{Sr} /{ }^{86} \mathrm{Sr}$ ratios as discussed below. The concentrations of the major oxides were then determined from graphical extrapolations of the linear relationships between the concentrations of strontium and those of other elements. 
Table 3. Estimated concentrations of major oxides in the parent basalt magma and in the contaminant

\begin{tabular}{|c|c|c|c|}
\hline & $\begin{array}{l}\text { Parent basalt } \\
\text { magma }\end{array}$ & Contaminant & Comments \\
\hline${ }^{87} \mathrm{Sr} /{ }^{86} \mathrm{Sr}$ & 0.706 & 0.720 & assumed \\
\hline $\mathrm{Sr}(\mathrm{ppm})$ & 117 & 173 & equation 4 \\
\hline $\mathrm{SiO}_{2}(\%)$ & 52.9 & 66.7 & $\mathrm{Sr}$ vs. $\mathrm{SiO}_{2}$ omitted 1 and 10 \\
\hline $\mathrm{TiO}_{2}$ & 1.76 & 0.60 & $\mathrm{SiO}_{2}$ vs. $\mathrm{TiO}_{2}$, omitted $1,11,12$ \\
\hline $\mathrm{Al}_{2} \mathrm{O}_{3}$ & 15.4 & 7.1 & $\mathrm{SiO}_{2}$ vs. $\mathrm{Al}_{2} \mathrm{O}_{3}$, omitted 1 and 12 \\
\hline $\mathrm{FeO}^{\mathrm{a}}$ & 9.0 & 16.6 & $\mathrm{SiO}_{2}$ vs. $\mathrm{FeO}$, omitted $4,5,11$ and 12 \\
\hline $\mathrm{MnO}$ & 0.30 & $\sim 0$ & $\mathrm{SiO}_{2}$ vs. $\mathrm{MnO}$, omitted 1 and 11 \\
\hline $\mathrm{MgO}$ & 4.9 & $\sim 0$ & $\mathrm{SiO}_{2}$ vs. $\mathrm{MgO}$, set III only \\
\hline $\mathrm{CaO}$ & 11.0 & 1.2 & $\mathrm{SiO}_{2}$ vs. $\mathrm{CaO}$, omitted 1 and 12 \\
\hline $\mathrm{Na}_{2} \mathrm{O}$ & 1.7 & 4.5 & $\mathrm{SiO}_{2}$ vs. $\mathrm{Na}_{2} \mathrm{O}$, omitted flow 1 \\
\hline $\mathbf{K}_{2} \mathbf{O}$ & 0.76 & 3.1 & $\mathrm{SiO}_{2}$ vs. $\mathrm{K}_{2} \mathrm{O}$, omitted 1,11 and 12 \\
\hline $\mathbf{P}_{2} \mathrm{O}_{5}$ & 0.06 & 0.41 & $\mathrm{SiO}_{2}$ vs. $\mathrm{P}_{2} \mathrm{O}_{5}$, omitted flow 12 \\
\hline
\end{tabular}

a Total iron as FeO.

We assume, with good reason, that one of the components was a magma of basaltic composition. It is known that such magmas have ${ }^{87} \mathrm{Sr} /{ }^{86} \mathrm{Sr}$ ratios of $0.704 \pm 0.002$, although somewhat higher values occur in some continental basalts (Faure and Powell, 1972). The other component, referred to as the contaminant, differed from the basalt magma component by having higher concentrations of $\mathrm{SiO}_{2}$, iron as $\mathrm{FeO}, \mathrm{Na}_{2} \mathrm{O}, \mathrm{K}_{2} \mathrm{O}, \mathrm{P}_{2} \mathrm{O}_{5}$ and strontium. On the other hand, it had significantly lower concentrations of $\mathrm{TiO}_{2}, \mathrm{MgO}, \mathrm{CaO}$ and $\mathrm{Al}_{2} \mathrm{O}_{3}$ than the basalt component. Regardless of the manner in which it became mixed with the basalt magma, the contaminant appears to have had a chemical composition resembling that of iron-rich granitic rocks. It is plausible therefore to suggest that the contaminant was derived from the igneous and metamorphic rocks of the crystalline basement complex of the Queen Alexandra Range. Gunner and Faure (1972) showed that the metamorphic rocks of this region (Nimrod Group) may be more than 2 billion years old and that they are significantly enriched in radiogenic ${ }^{87} \mathrm{Sr}$. According to unpublished analyses by Gunner (1971), these metamorphic rocks had an average composite ${ }^{87} \mathrm{Sr} /{ }^{86} \mathrm{Sr}$ ratio of about 0.723 during the Jurassic period 170 million years ago. This value is in good agreement with previous estimates of the average ${ }^{87} \mathrm{Sr} /{ }^{86} \mathrm{Sr}$ ratios of Precambrian metamorphic rocks which range from 0.715-0.725 (Faure and Powell, 1972). This information helps to set limits on the possible major oxide concentrations of the basaltic and granitic components.

On the basis of these considerations we assumed reasonable values of 0.706 and 0.720 for the ${ }^{87} \mathrm{Sr} /{ }^{86} \mathrm{Sr}$ ratios of the parent basalt and the contaminant, respectively. Substitution of these values into equation 4 yields strontium concentrations of $117 \mathrm{ppm}$ for the parent basalt and $173 \mathrm{ppm}$ for the contaminant. The concentrations of $\mathrm{SiO}_{2}$ of the end-members were then determined by extrapolation of a straight line fitted to a plot of the concentrations of strontium and silica in the flows. The resulting estimated concentrations of $\mathrm{SiO}_{2}$ are $52.9 \%$ for the basalt magma and $66.7 \%$ for the contaminant. The concentrations of the 
remaining oxides were determined similarly from plots of $\mathrm{SiO}_{2}$ versus the other oxides. The results are listed in Table 3. In most cases the fit of data points to straight mixing lines is satisfactory and is further improved when points are shifted to their respective reference lines drawn in Figure 3. Such linear relationships between concentrations of major oxides or trace elements in suites of volcanic rocks are usually attributed to fractional crystallization. The correlation of concentrations with initial ${ }^{87} \mathrm{Sr} /{ }^{86} \mathrm{Sr}$ ratios (Fig. 5) makes clear that in this case such relationships are probably the result of contamination.

The chemical composition of the basalt magma component that is derived by this treatment of the data is quite reasonable when compared to the average chemical composition of continental and oceanic tholeiites (Table 2, columns B and C). The most notable feature of the basalt component is its low strontium concentration $(117 \mathrm{ppm})$ which is similar to that of oceanic tholeiite. However, its other components are not characteristic of oceanic tholeiites. The chemical composition of the contaminant is charcterized by high concentrations of $\mathrm{SiO}_{2}(66.7 \%$, $\mathrm{FeO}(16.6 \%), \mathrm{Na}_{2} \mathrm{O}(4.5 \%)$ and $\mathrm{K}_{2} \mathrm{O}(3.1 \%)$. The concentrations of $\mathrm{Al}_{2} \mathrm{O}_{3}(7.1 \%)$ $\mathrm{MgO}(\sim 0 \%)$ and $\mathrm{CaO}(1.2 \%)$ are low. In general, the chemical composition of the contaminant appears to be compatible with that of a partial melt derived from granitic rocks.

Finally, we calculate the concentration of contaminant in weight percent in the basalt flows on Storm Peak based on the data for strontium. For that purpose Eq. (1) is rewritten as:

$$
P=\frac{\mathrm{Sr}_{B}-\mathrm{Sr}_{M}}{\mathrm{Sr}_{M}-\mathrm{Sr}_{C}}
$$

Setting $\mathrm{Sr}_{B}=117 \mathrm{ppm}, \mathrm{Sr}_{C}=173 \mathrm{ppm}$ we solve Eq. (5) for $P$ by substituting the highest and lowest strontium concentration of the flows: $\operatorname{Sr}_{M}=138.6 \mathrm{ppm}$ (maximum, flow 6) and $\mathrm{Sr}_{M}=127.6 \mathrm{ppm}$ (minimum, flow 12). The strontium concentrations of flows 4 and 10 are anomalously low as noted before. The resulting values of $P$ are 0.64 and 0.24 , respectively. The data for strontium therefore indicate that the concentration of the contaminant in the flows on Storm Peak varies from about $20-40$ per cent by weight.

We believe that a complete explanation of the petrogenesis of the Jurassic basalt flows and diabase sills in the Transantaretic Mountains must include the tectonic framework within which these rocks were formed. The extrusion of basalt during the Mesozoic era in South America, South Africa and Antarctica is probably associated with the break-up of Gondwanaland which must have been caused by lateral motions of the asthenosphere under the lithospheric plate of Gondwanaland. It is possible, therefore, that basalt magma was generated in sub-crustal sources by adiabatic decompression, perhaps in linear belts associated with rising plumes of the convecting asthenosphere. Such a tectonic setting seems capable of explaining the formation of very large quantities of basalt magma in a belt extending for over $2700 \mathrm{~km}$ in Antarctica alone. The basalt magma was then intruded into the continental crust composed of igneous and metamorphic rocks of granitic composition and of Precambrian age. According to evidence pub. lished previously by Faure et al. (1972), the basalt magma was hybridized by assimilation of varying amounts of granitic material throughout the entire 
length of the Transantarctic Mountains, including Tasmania which was originally attached to the East Antarctic plate.

\section{Summary}

The evidence and conclusions presented in this paper can be summarized as follows:

1. The initial ${ }^{87} \mathrm{Sr} /{ }^{86} \mathrm{Sr}$ ratios of the basalt flows (Jurassic) on Storm Peak are anomalously high compared to basaltic rocks elsewhere and have an average value of $0.7112 \pm 0.0013$. These basalts also have unusually high concentrations of rubidium $(60.6 \pm 19.4 \mathrm{ppm})$ and low concentrations of strontium (128.8土 $11.9 \mathrm{ppm}$ ) which gives them a $\mathrm{Rb} / \mathrm{Sr}$ ratio 0.47 that is anomalously high for basalts.

2. The initial ${ }^{87} \mathrm{Sr} /{ }^{86} \mathrm{Sr}$ ratios and all chemical parameters of these lava flows vary systematically in a stratigraphic sense on the basis of which four eruptive episodes can be identified.

3. The positive correlation between initial ${ }^{87} \mathrm{Sr} /{ }^{86} \mathrm{Sr}$ ratios and strontium concentrations rules out the possibility that these flows are the products of crystal fractionation in a closed system. Instead, this correlation can be satisfactorily explained by the interactions of a parent basalt magma with granitic rocks of Precambrian age.

4. The correlation of initial ${ }^{87} \mathrm{Sr} /{ }^{86} \mathrm{Sr}$ ratios of the flows with the concentrations of all of the major oxide components reinforces the mixing hypothesis. The linear relationships between concentrations of strontium and the major oxides can thus be used to estimate their concentrations in the end-members.

5. The interpretation of the data for strontium leads to the conclusion that the basalt flows on Storm Peak contain between 20 and 40 weight percent of contaminant enriched in $\mathrm{SiO}_{2}, \mathrm{FeO}$, alkali metals and strontium, but depleted in $\mathrm{Al}_{2} \mathrm{O}_{3}, \mathrm{CaO}$ and $\mathrm{MgO}$ compared to the parent basalt.

6. The origin of these hybrid basalts is related to the break-up of the Gondwanaland plate and to subsequent tectonic events in order to account for the wide-spread occurrence of these anomalous basalts in the Transantarctic Mountains and in Tasmania.

Acknowledgements. The field work on which this study is based was supported by the National Science Foundation through Grant GA-12315 to D. H. Elliot. The laboratory investigations were supported by NSF Grants GA-898X and GV-41037 to G. Faure. This paper is Contribution No. 257 of the Institute of Polar Studies.

\section{References}

Barrett, P. J.: Stratigraphy and petrology of the mainly fluviatile Permian and Triassic part of the Beacon Supergroup, Beardmore Glacier area. In: Antarctic Geology and Geophysics, R. J. Adie, ed., p. 365-372. Oslo: Universitetsforlaget 1972

Barrett, P. J., Elliot, D. H.: The early Mesozoic volcaniclastic Prebble Formation, Beardmore Glacier area. In: Antarctic Geology and Geophysics, R. J. Adie, ed., p. 403-409. Oslo: Universitetsforlaget 1972

Bowman, J. R.: Use of the isotopic composition of strontium and $\mathrm{SiO}_{2}$ content in determining the origin of Mesozoic basalt from Antarctica. Unpublished MSc. thesis, Dept. Geol., The Ohio State University, Columbus, Ohio, 179 pp. (1971)

Bowman, J. R., Faure, G., Elliot, D. H.: Isotope geochemistry of strontium of the Kirkpatrick Basalt, Storm Peak, Transantarctic Mountains. Abstracts with Programs, Geol. Soc. Am. 5, No. 7, 557 (1973) 
Compston, W., McDougall, I., Heier, K. S.: Geochemical comparison of the Mesozoic basaltic rocks of Antarctica, South Africa, South America and Tasmania. Geochim. Cosmochim. Acta 32, 129-149 (1968)

Elliot, D. H.: Jurassic tholeiitic basalts of the central Transantarctic Mountains, Antarctica. Proceed. Second Columbia River Basalt Symp., E. H. Gilmour, D. Stradling, eds., p. 301325. Cheney: Eastern Wash. State College Press 1970

Elliot, D. H.: Major oxide chemistry of the Kirkpatrick Basalt, central Transantaretic Mountains. In: Antarctic Geology and Geophysics, R. J. Adie, ed., p. 413-418. Oslo: Universitetsforlaget 1972

Elliot, D. H., Tasch, P.: Lioesteriid conchostracans: A new Jurassic locality and regional and Gondwana correlations. J. Paleont. 41, 1561-1563 (1967)

Faure, G., Hill, R. L.: The age of the Falla Formation (Triassic), Queen Alexandra Range. Ant. J. US. 7, 264-266 (1973)

Faure, G., Hill, R. L., Jones, L. M., Elliot, D. H.: Isotope composition of strontium and silica content of Mesozoic basalt and dolerite from Antaretica. In: Antarctic Geology and Geophysics, R. H. Adie, ed., p. 617-624. Oslo: Univeritetsforlaget 1972

Faure, G., Powell, J. L.: Strontium isotope geology, 188 pp. Berlin-Heidelberg-New York: Springer 1972

Ford, A. B., Boyd, W. W., Jr.: The Dufek Intrusion, a major stratiform gabbroic body in the Pensacola Mountains, Antaretica. XXIII Int. Geol. Congr. 2, 213-228 (1968)

Gunn, B. M.: Differentiation in Ferrar dolerites, Antaretica. New Zealand J. Geol. Geophys. $5,820-863(1962)$

Gunn, B. M.: $\mathrm{K} / \mathrm{Rb}$ and $\mathrm{K} / \mathrm{Ba}$ ratios in Antarctic and New Zealand tholeiites and alkali basalts. J. Geophys. Res. 70, 6241-6247 (1965)

Gunn, B. M.: Modal and element variation in Antarctic tholeiites. Geochim. Cosmochim. Acta, 30 881-920 (1966)

Gunner, J.: Age and origin of the Nimrod Group and of the Granite Harbour Instrusives, Beardmore Glacier region, Antaretica. Unpubl. Ph. D. Dissert., Dept. Geology, The Ohio State University, 231 pp. (1971)

Gunner, J., Faure, G.: Rb-Sr geochronology of the Nimrod Group, central Transantarctic Mountains. In: Antaretic Geology and Geophysics, R. J. Adie, ed., p. 305-311. Oslo: Universitetsforlaget 1972

Hamilton, W.: Diabase sheets of the Taylor Glacier region, Victoria Land, Antarctica. U.S. Geol. Surv. Profess. Papers 456-B, 1-71 (1965)

Heier, K. S., Compston, W., MeDougall, I.: Thorium and uranium concentrations, and the isotopic composition of strontium in the differentiated Tasmanian dolerites. Geochim. Cosmochim. Acta 29, 643-659 (1965)

Hill, R. L.: Strontium isotope composition of basaltic rocks of the Transantaretic Mountains, Antarctica. Unpublished M.Sc. thesis, The Ohio State University, Columbus, 87 pp. (1969)

Manson, V.: Geochemistry of basaltic rocks; Major elements. In: Basalts, H. H. Hess, ed., vol. 1, p. 213-269. New York: Interscience 1967

McDougall, I.: Differentiation of the Tasmanian dolerites: Red Hill dolerite-granophyre association. Geol. Soc. Am. Bull. 73, 279-315 (1962)

Prinz, M.: Geochemistry of basaltic rocks: Trace elements. In: Basalts, H. H. Hess, ed., vol. 1, p. 272-323. New York: Interscience 1967

Pushkar, P., MeBirney, A. R., Kudo, A. M.: The isotopic composition of strontium in Central American ignimbrites. Bull. Volcanol. 35, 265-294 (1972)

Schaeffer, B.: A Jurassic fish from Antaretica. Am. Mus. Novitates, No. 2395, 1-17 (1972)

Tatsumoto, M., Hedge, C. E., Engel, A. E. J.: Potassium, rubidium, strontium, thorium, uranium and the ratio strontium -87 to strontium -86 in oceanic tholeiite basalt. Science 150, 886-888 (1965)

Dr. G. Faure

Department of Geology and Mineralogy

The Ohio State University

Columbus, Ohio 43210 , U.S.A. 